\title{
DIFFUSION PLATE ASSAY FOR CHLORAMPHENICOL AND AUREOMYCIN ${ }^{1}$
}

\author{
By W. A. RANDAll, A. Kirshbaum, J. K. NiElsen, and D. Wintermere
}

(From the Federal Security Agency, Food and Drug Administration, Washington, D. C.)

In the development of bioassay methods for antibiotics a certain standard pattern is usually followed. First, a wide variety of microorganisms are tested for their sensitivity to the new drug and then sensitive strains are selected and tested for their suitability for use in a plate assay, turbidimetric assay and serial dilution assay. Since the Food and Drug Administration tests a number of antibiotics, every effort is made to adapt test procedures for new antibiotics to those already in use. Thus, in the two plate assay methods to be described, it has been found possible to utilize the same test organism; the same medium as that used in the seed layer for the penicillin plate assay; and the general procedure for determining the potency of an unknown which is the same as that described for penicillin in the Federal Register of June 3, 1948.

The percentage error of the assay may be determined by the double dose technic described by Knudsen and Randall (1). A 1:4 ratio is used for chloramphenicol $(20 \mu \mathrm{g}$. and $80 \mu \mathrm{g}$.), and a 1:10 ratio for aureomycin ( $3 \mu \mathrm{g}$. and $30 \mu \mathrm{g}$.) . The chart and nomograph for the $1: 10$ ratio are not given in the above publication but may be obtained on request from the Food and Drug Administration. The percentage error of the chloramphenicol plate assay has averaged $2.23 \%$ on about 21 determinations with a range of from $0.7 \%$ to $4.58 \%$. The error of the aureomycin assay is somewhat higher. In 24 determinations the percentage error ranged from $2.5 \%$ to $14.8 \%$ with an average of $7.4 \%$. In our experience the cupplate method for chloramphenicol is the most accurate and reproducible one yet encountered. A composite curve was prepared from ten daily chloramphenicol curves and the potency of samples previously run recalculated. Since no significant differences in potency were noted, a daily curve is

1 Presented at the Second National Symposium on Recent Advances in Antibiotics Research held in Washington, D. C., April 11-12, 1949, under the auspices of the Antibiotics Study Section, National Institutes of Health, Public Health Service, Federal Security Agency. no longer necessary; however, the composite curve is checked against a new standard curve once every week. A description of the methods follows.

Culture media. Use ingredients that conform to the standards prescribed by the U.S.P. or N.F. Make nutrient agar for the seed and base layer and for carrying the test organism as follows:

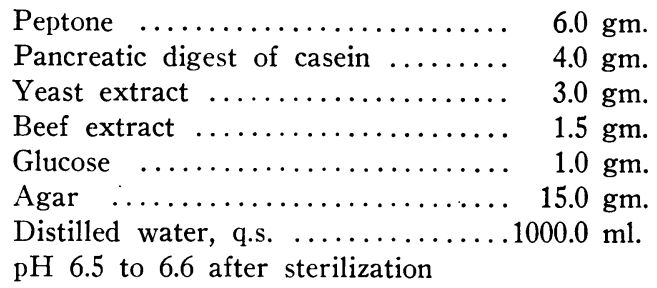

Make nutrient broth, for preparing a suspension of the test organism, as follows :

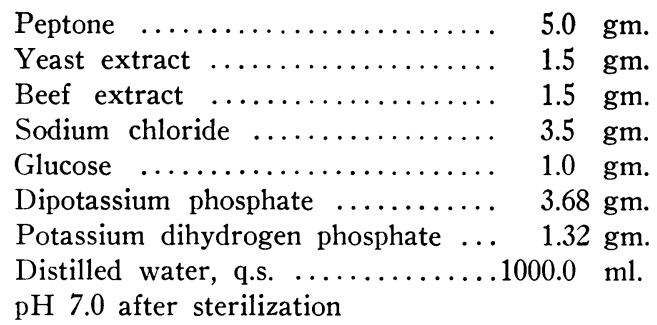

In lieu of preparing the media from the individual ingredients specified above, they may be made from a dehydrated mixture which, when reconstituted with distilled water, has the same composition as such media.

\section{Working standard}

A. Chloramphenicol. Weigh out carefully appropriate amounts of the standard which is crystalline synthetic chloramphenicol and dilute in 1\% phosphate buffer $\mathrm{pH} 6$ to give a solution containing $100 \mu \mathrm{g}$. per $\mathrm{ml}$. Keep this stock solution at a temperature of $15^{\circ} \mathrm{C}$. or less, and use for only one week. From this stock solution make appropriate working dilutions in the above buffer. To facilitate solutions, the standard may be first dissolved in a small amount of ethyl alcohol.

B. Aureomycin. Proceed as above except dilute the aureomycin standard which is crystalline aureomycin to $1000 \mu \mathrm{g}$. per $\mathrm{ml}$. in $1 \%$ potassium acid phthalatetartaric acid buffer $\mathrm{pH} 3.0$ and use for only three days.

Preparation of sample.

A. Chloramphenicol. Dissolve the sample to be tested in a small amount of ethyl alcohol and then further dilute 
in $1 \%$ phosphate buffer $\mathrm{pH} 6$ to make an appropriate stock solution.

B. Aureomycin. Dissolve the sample to be tested in sterile distilled water to make an appropriate stock solution.

\section{Preparation of plates}

I. Base layer. Add $21 \mathrm{ml}$. of agar to each Petri dish $(20 \times 100 \mathrm{~mm}$. $)$. Distribute the agar evenly in the plates and allow it to harden. Use the plates the same day they are prepared.

II. Seed layer. The test organism is Sarcina lutea (P.C.I. 1001). Maintain the test organism on slants of nutrient agar prepared as described above, and transfer to a fresh agar slant once a week. Prepare a suspension of the test organisms as follows : Streak an agar slant heavily with the test organism. Incubate 24 hours at $26^{\circ} \mathrm{C}$. Wash the growth off in about $3 \mathrm{ml}$. of nutrient broth. Use the suspension so obtained to inoculate the surface of a Roux bottle containing $300 \mathrm{ml}$. of the above agar. Spread the suspension over the entire surface with the aid of sterile glass beads. Incubate 24 hours at $26^{\circ} \mathrm{C}$.

A. Chloramphenicol. Wash the resulting growth from the agar surface with about $20 \mathrm{ml}$. of nutrient broth. If an aliquot of this bulk suspension, when diluted with nutrient broth $1: 10$, gives a $10 \%$ light transmission, the bulk suspension is satisfactory for use in the test. It may be necessary to dilute the bulk suspension so that a $1: 10$ dilution of an aliquot gives a light transmission of $10 \%$. A photoelectric colorimeter equipped with a filter having a wave length of 6500 Angstrom units is used in the standardization. The bulk suspension may be used in the test for one week or longer. Add $1.5 \mathrm{ml}$. of the adjusted bulk suspension to $100 \mathrm{ml}$. of agar which has been melted and cooled to $48^{\circ} \mathrm{C}$. Use $4 \mathrm{ml}$. per plate of this inoculum for the seed layer.

$B$. Aureomycin. Wash the growth from the agar surface with $50 \mathrm{ml}$. of nutrient broth. If an aliquot of this bulk suspension when diluted $1: 50$ in saline gives $75 \%$ light transmission (filter same as above), the bulk suspension is satisfactory for use in the test. As above, it may be necessary to dilute the bulk suspension so that an aliquot gives $75 \%$ light transmission. The bulk suspension may be used in the test for at least one week. Add $0.3 \mathrm{ml}$. of the adjusted bulk suspension to $100 \mathrm{ml}$. of agar which has been melted and cooled at $48^{\circ} \mathrm{C}$. Use $4 \mathrm{ml}$. per plate of this inoculum for the seed layer.

\section{Assay}

A. Chloramphenicol. The potency of the sample is determined by the standard curve technic, using a single dose of standard and unknown.

Dilute the sample to be tested to an estimated 50 $\mu \mathrm{g}$. per $\mathrm{ml}$. in $1 \%$ phosphate buffer $\mathrm{pH} 6$. Place six cylinders on the inoculated agar surface so that they are at approximately $60^{\circ}$ intervals on a $2.8 \mathrm{~cm}$. radius. Use three plates for each sample.
Fill three cylinders on each plate with the $50 \mu \mathrm{g}$. per ml. standard and three cylinders with the 50 $\mu$. per $\mathrm{ml}$. (estimated) sample, alternating standard and sample. At the same time prepare a standard curve, using concentrations of the standard of 30.0, 35.0, 40.0, 45.0, 50.0, 55.0, 60.0, 65.0, and $70.0 \mu \mathrm{g}$. per $\mathrm{ml}$. A total of 24 plates is used in the preparation of the standard curve, three plates for each solution except the $50 \mu \mathrm{g}$. per $\mathrm{ml}$. solution. The latter concentration is used as the reference point and is included on each plate. On each of three plates fill three cylinders with the $50 \mu \mathrm{g}$. per ml. standard and the other three cylinders with the concentration of the standard under test. Thus, there will be seventy-two 50$\mu \mathrm{g}$. determinations and nine determinations for each of the other points on the curve. Incubate the plates for 16 to 18 hours at $37^{\circ} \mathrm{C}$. and measure the diameter of each circle of inhibition. Average the readings of the $50 \mu \mathrm{g}$. per $\mathrm{ml}$. concentration and the readings of the point tested for each set of three plates, and average also all 72 readings of the $50 \mu \mathrm{g}$. per $\mathrm{ml}$. concentration. The average of the 72 readings of the $50 \mu \mathrm{g}$. per $\mathrm{ml}$. concentration is the correction point for the curve. Correct the average value obtained for each point to the figure it would be if the $50 \mu \mathrm{g}$. per $\mathrm{ml}$. reading for that set of three plates were the same as the correction point. Thus, if in correcting the $40 \mu \mathrm{g}$. per $\mathrm{ml}$. concentration the average of the 72 readings of the $50 \mu \mathrm{g}$. per ml. concentration is $18.0 \mathrm{~mm}$., and the average of the $50 \mu \mathrm{g}$. per $\mathrm{ml}$. concentration of this set of three plates is $17.8 \mathrm{~mm}$., the correction is .2 $\mathrm{mm}$. If the average reading of the $40 \mu \mathrm{g}$. per $\mathrm{ml}$. concentration of these same three plates is 17.0 $\mathrm{mm}$., the corrected value is then $17.2 \mathrm{~mm}$.

Plot these corrected values including the average of the $50 \mu \mathrm{g}$. per ml. concentrations on twocycle semi-log paper, using the concentration in $\mu \mathrm{g}$. per $\mathrm{ml}$. as the ordinate (the logarithmic scale) and the diameter of the zone of inhibition as the abscissa. Draw the standard curve through these points.

To estimate the potency of the sample, average the zone readings of the standard and the zone readings of the sample on the three plates used. If the sample gives a larger zone size than the average of the standard, add the difference between them to the $50 \mu \mathrm{g}$. per ml. unit zone on the stand- 
ard curve. If the average value is lower than the standard value, subtract the difference between them from the $50 \mu \mathrm{g}$. per $\mathrm{ml}$. unit value on the curve. From the curves read the potencies corresponding to these corrected values of zone sizes.

B. Aureomycin. The assay for aureomycin follows very closely that described for chloramphenicol. The following exceptions are noted.

1. Dilute the stock solution of the sample to be tested to $10.0 \mu \mathrm{g}$. per ml. (estimated) in $1 \%$ potassium acid phthalate-tartaric acid buffer $(\mathrm{pH}$ 3.0).

2. Prepare a standard curve, using concentrations of the standard of 4.0,6.0, 8.0, 10.0, 13.0, 17.0, 22.0, and $29.0 \mu \mathrm{g}$. per ml. in $1 \%$ potassium acid phthalate-tartaric acid buffer $\mathrm{pH}$ 3.0. The
$10 \mu \mathrm{g}$. per ml. concentration is the reference point for the aureomycin curve, and the correction point is obtained by averaging the readings of all of the $10 \mu \mathrm{g}$. per ml. concentrations.

\section{SUMMARY}

1. A cup-plate assay for chloramphenicol and aureomycin is described.

2. The organism, medium and the general method for estimating the potency are the same for both antibiotics.

\section{BIBLIOGRAPHY}

1. Knudsen, L. F., and Randall, W. A., Penicillin assay and its control chart analysis. J. Bact., 1945, 50, 187. 